\title{
PENGUKURAN KINERJA PERUSAHAAN DENGAN MENGGUNAKAN METODE BALANCED SCORECARD (BSC) DAN OBJECTIVE MATRIX (OMAX)
}

\author{
Wahyu Eko Cahtono \& Heris Subiyono \\ Fakultas Teknik, Universitas "WR. Supratman” Surabaya, \\ SMP Negeri 1 Gembong - Pati
}

\begin{abstract}
ABSTRAKSI
Balanced Scorecard merupakan suatu sistem manajemen, pengukuran, dan pengendalian yang secar tepat dan tepat dan secara menyeluruh yang dapat memberikan kerangaka kerja dan berfikir yang integrasif serta pemahaman manajer tentang performance bisnis. Pengukuran kinerja tersebut memandang unit bisnis dari empat perspektif, yaitu perspektif keuangan, pelanggan, proses bisnis internal, pertumbuhan dan pembelajaran. Melalui mekanisme sebab akibat, perspektif keuangan menjadi tolak ukur utama yang dijelaskan untuk tolak ukur operasioanal pada tiga perspektif lainya sebagai lead indicators.

Berdasarkan hasil pengukuran kinerja dengan menggunakan metode Balanced Scorecard dan Objective Matrix dapat disimpulkan bahwa kinerja di Balai Pelayanan Teknis Industri Logam dan LIK Sidoarjo mengalami peningkatan sebesar 0.42 dari tahun sebelumnya, tetapi performansinya harus tetap ditingkatkan lagi karena masih berada didalam indikator kuning.

Hasil dari pengukuran kinerja ini dapat digunakan sebagai bahan masukkan guna meningkatkan kinerja yang ingin dicapai di Balai Pelayanan Teknis Industri Logam dan LIK Sidoarjo, serta dapat menghasilkan suatu rancangan kinerja yang berguna dalam meningkatkan kinerja perusahaan.
\end{abstract}

Kata Kunci : Pengukuran Kinerja perusahaan, Balanced ScoreCard, Objective Matrix.

\section{PENDAHULUAN}

Persaingan yang semakin ketat pada masa sekarang ini memaksa perusahaan-perusahaan untuk meningkatkan kinerjanya agar dapat bertahan dan berkembang antara lain melalui peningkatan mutu produk yang dihasilkan. Jika perusahaan ingin dapat bersaing dalam dunia kompetisi, maka perusahaan tersebut harus memiliki sistem pengukuran dan manajemen yang diambil dari strategi dan kemampuan perusahaan itu sendiri.

Salah satu alat manajemen strategi yang dapat membantu perusahaan untuk terus meningkatkan kemampuan strategisnya adalah Balanced ScoreCard (BSC). Dengan menggunakan Balanced ScoreCard (BSC) diharapkan perusahaan dapat menterjemahkan visi, misi dan strategi perusahaan ke dalam seperangkat ukuran yang menjadi kerangka kerja bagi pengukuran dan sistem manajemen strategis perusahaan.

Terdapat juga metode yang digunakan dalam pengukuran kinerja di perusahaan yaitu metode OMAX (Objective Matrix). Penggunaan metode OMAX dalam pengukuran kinerja di perusahaan ini adalah sebagai tolak ukur pencapaian kinerja suatu perusahaan berdasarkan kriteria yang telah ditetapkan perusahaan. 
Seiring dengan persaingan yang semakin ketat dalam menghadapi tantangan persaingan bisnis di bidang manufaktur, BPTI Logam Sidoarjo sebagai perusahaan yang bergerak dibidang industri manufaktur, dengan sistem produksinya adalah job shop. ingin melakukan perbaikan terhadap sistem yang selama ini berjalan di balai, ini dikarenakan indikator sistem pengukuran kinerja yang selama ini berjalan di BPTI Logam Sidoarjo hanya mengacu pada laporan keuangan atau finansial.

\section{TINJAUAN PUSTAKA}

\section{Perspektif Pertumbuhan dan Pembelajaran (Learning \& Growth).}

Tujuan dari perspektif ini adalah menyediakan infrastruktur yang memungkinkan tujuan ambisius dalam tiga perspektif lain dapat dicapai. Proses pembelajaran dan pertumbuhan organisasi berdasarkan tiga kategori utama (Kaplan dan Norton, 1996), yaitu:

a. Kapabilitas pekerja (employee capabilities).

Tolak ukur yang digunakan antara lain: tingkat kepuasan kerja para pegawai (employee satisfaction), tingkat perputaran para pegawai, besarnya pendapatan perusahaan per pegawai, nilai tambah per pegawai, tingkat pengembalian balas jasa.

b. Kapabilitas sistem informasi (information systems capabilities).

Tolak ukur yang digunakan antara lain: tingkat ketersediaan informasi yang dibutuhkan, tingkat ketepatan informasi yang tersedia, dan jangka waktu untuk memperoleh informasi yang dibutuhkan.

c. Motivasi, pemberdayaan, dan keselarasan (motivation, empowerment, and alignment).

Tolak ukur yang yang digunakan antara lain jumlah saran per pegawai, jumlah saran yang diimplementasi serta banyaknya pegawai yang mengetahui dan mengerti visi dan objectives perusahaan.

\section{Key Success Faktor Dalam Empat Perspektif}

Dalam Balanced ScoreCard dibagi menjadi empat sudut pandang. Pengelompokan key success faktor dapat dilakukan menurut empat sudut pandang yang dijelaskan sebagai berikut :

\section{A. Pengukuran Perspektif Finansial.}

Pengukuran-pengukuran finansial yang digunakan sebagai indikator dalam mengevaluasi kinerja badan usaha antara lain :

\section{1) Current Ratio}

Current Ratio merupakan rasio yang mengukur kemampuan perusahaan untuk membayar hutang-hutang lancarnya dengan aktiva lancar yang dimiliki sesuai dengan pernyataan Weston, Brigham (1986:28). Rasio ini dinyatakan dengan membandingkan antara current assets dengan current liabilities. Current ratio yang tinggi menunjukkan perusahaan banyak memiliki current assets untuk dapat menjamin current liabilities yang dimilikinya.

$$
C R=\frac{\text { current assets }}{\text { current liabilities }}
$$

\section{2). Total Assets Turn Over}


Menurut Weston, Brigham ( 1986:35), “total assets turnover” mengukur efisiensi pengaturan seluruh aset perusahaan. Semakin tinggi TATO suatu perusahaan semakin maka semakin efisien aset-aset perusahaan yang digunakan untuk menghasilkan penjualan. Selain itu ukuran ini menunjukkan pembiayaan biaya operasi perusahaan secara efisien. Dalam evaluasi perlu diperhatikan modernisasi perawatan yang dapat menyebabkan penurunan TATO, juga kelayakan aset yang digunakan untuk penyesuaian dan langkah antisipasi dalam persaingan.

$$
\text { TATO }=\frac{\text { net sales }}{\text { average total assets }}
$$

\section{3). Profit Margin on Sales}

Profit margin menunjukkan besarnya laba bersih untuk setiap penjualan bersih. Faktor utama yang dapat mempengaruhi profit margin yaitu efisiensi biaya operasi dan peningatan harga jual. Oleh karena tingkat profitabilitas diukur dengan menggunakan rasio laba bersih atas penjualan bersih, maka peningkatan profit dapat dicapai dengan melakukan peningkatan terhadap faktor-faktor yang mempengaruhi profit margin tersebut. Namun demikian peningkatan harga jual untuk meningkatkan profit margin dapat berpengaruh negatif terhadap kualitas penjualan produk dan akibatnya akan berdampak langsung pada omset penjualan badan usaha.

Profit margin yang tinggi memberikan informasi bahwa badan usaha tersebut mempunyai kemampuan manajemen untuk menciptakan pendapatan yang cukup guna memenuhi biaya-biaya manufaktur, operasi dan pinjaman disamping memberikan keuntungan bagi badan usaha sebagai pengembalian atas investasi yang dilakukan.

Weston, Brigham (1992:186) merumuskan profit margin on sales sebagai besarnya prosentase yang didapat dari pembagian net income dengan penjualan.

\section{4). Return On Equity}

$$
P M o S=\frac{\text { net income }}{\text { sales }}
$$

Return on equity merupakan alat yang digunakan untuk mengukur kemampuan badan usaha untuk menghasilkan laba, tapi lebih ditekankan pada pengoptimalan pengembalian pada para pemegang saham (Stakeholders). Return on equity adalah ukuran bagaimana dana yang dikeluarkan pemegang saham sepanjang tahun. Karena keuntungan pemegang saham merupakan tujuan perusahaan, maka dapat dikatakan bahwa return on equity merupakan pengukuran kinerja secara bottom line yaitu menilai kinerja dari hasil akhirnya saja.

Pemakaian ROE menggunakan denominator shareholder equity karena dengan tertanamnya saham dari shareholder menyebabkan dana tidak dapat digunakan untuk kepentingan yang lain sehingga perlu dilihat berapa tingkat pengembalian dari equity yang diperoleh shareholder untuk dibandingkan dengan opportunity yang hilang dari modal yang ditanamkan tersebut.

$$
R O E=\frac{\text { net income }}{\text { shareholder equity }}
$$




\section{5) Return On Assets}

Return On Assets menghubungkan hasil-hasil kinerja operasi dengan investasi perusahaan tanpa mempedulikan bagaimana perusahaan mendanai pembelian investasi tersebut. Dengan demikian ROA berupaya untuk mengukur keberhasilan perusahaan dalam menciptakan dan menjual barang dan jasa kepada para pelanggan, aktivitas-aktivitas umumnya merupakan tanggung jawab departemen produksi dan departemen pemasaran (Simamora, 1999:358). Dengan kata lain $R O A$ menggambarkan perbaikan atas kinerja operasi dan mengukur efisiensi dari total aset untuk menghasilkan profit. Bila tidak ada perubahan harga jual dan tidak ada investasi baru pada peralatan tetapi rasio membaik maka dapat dikatakan bahwa penggunaan dari aset yang lebih selektif. ROA ditentukan dengan cara membagi jumlah laba bersih dengan jumlah aktiva.

$$
R O A=\frac{\text { net income }}{\text { total assets }}
$$

\section{6) Return Of investment}

Merupaka alat untuk mengukur kemampuan badan usaha untuk menghasilkan laba, tetapi dengan lebih menekankan pada penggunaan assets secara efisien.

$$
\mathrm{ROI}=\frac{\text { Lab_bersih_Setelah_pajak }}{\text { Jumlah_aktiva }}
$$

\section{B. Pengukuran Perspektif Pelanggan.}

Beberapa kategori yang berpengaruh terhadap pengambilan keputusan konsumen dalam pengukuran kinerja perusahaan antara lain:

\section{1) Customer Retention}

Mempertahankan konsumen yang dimiliki merupakan suatu cara untuk menjaga dan mengembangkan pangsa pasar. Customer retention dapat menunjukkan kemampuan perusahaan dalam mempertahankan dan menjaga hubungan baik dengan konsumen terus menerus. Besarnya customer retention akan memberikan petunjuk tentang loyalitas konsumen.

2). Number of New Customer

Pengukuran ini dilakukan sebagai salah satu ukuran dari customer acquisition. Number of new customer menunjukkan perkembangan pemasaran perusahaan. Pengukuran dapat dilakukan dengan membandingkan jumlah pelanggan dengan seluruh pelanggan saat ini.

\section{3). On Time Delivery Performance}

Konsumen menginginkan pesanan mereka diterima secara tepat dan akurat. Pelaksanaan pengiriman tepat waktu menunjukkan situasi dimana produk atau jasa benar-benar diantarkan tepat sesuai dengan waktu yang sudah dijadwalkan, sedangkan untuk mengukur kinerja pengiriman tepat waktu menurut Hansen dan Mowen (1994:960) adalah dengan membagi pesanan yang dikirim tepat waktu dengan jumlah pesanan yang dikirim.

$$
O T D=\frac{\text { jumlah pesanan yang dikirim tepat waktu }}{\text { jumlah pesanan yang dikirim }}
$$

\section{4) Sales Return}


Produk yang dikembalikan pada perusahaan merupakan ketidakmampuan perusahaan dalam memenuhi pesanan konsumen sesuai dengan spesifikasi yang telah dijanjikan. Dengan pelayanan yang baik konsumen akan puas dan pihak perusahaan tidak akan kehilangan pelanggannya.

\section{5) Number of Complaints}

$$
\text { Rasio retur penjualan }=\frac{\text { jumlah retur penjualan }}{\text { jumlah produk terjual }}
$$

Jumlah keluhan pelanggan menunjukkan bahwa konsumen kurang puas dengan produk yang kita hasilkan karena sebab seperti keterlambatan pengiriman, produk cacat dan lainnya. Jumlah komplain yang rendah dapat meningkatkan kepercayaan konsumen sehingga diharapkan dapat meningkatkan image dan persepsi konsumen terhadap produk dan perusahaan.

$$
\text { Number of Complaint } s=\frac{\text { jumlah keluhan }}{\text { jumlahtransaksi }} \times 100 \%
$$

\section{Pengukuran Proses Bisnis Internal.}

Penilaian kinerja internal suatu perusahaan dapat dilakukan dengan menggunakan beberapa variable pengukuran antara lain :

1) Percentage Sales of New Product

Pengukuran ini dapat dijadikan tolak ukur keberhasilan dalam proses inovasi. Tingginya percentage sales of new product menunjukkan besarnya perbandingan antara produk baru yang terjual dengan penjualan yang sudah ada, artinya produk baru dapat diterima dan direspon baik oleh konsumen.

2) Yield Rate

Yield rate merupakan pengukuran kualitas yang menggambarkan kemampuan perusahaan dalam menghasilkan produk. Yield rate menurut Kaplan dan Norton (1996:101) adalah rasio dari barang baik yang dihasilkan dengan barang baik yang memasuki proses. Yield rate dapat dihitung dengan membagi jumlah produk baik-baik yang dihasilkan perusahaan dengan jumlah total produksi perusahaan.

$$
\text { Yield rate }=\frac{\text { jumlah produk baik yang dihasilkan }}{\text { jumlah total produk yang dihasilkan }} \times 100 \%
$$

\section{3) Supplier Lead Time}

Supplier lead time menyatakan waktu rata-rata yang diperlukan supplier untuk mengirim barang yang dipesan yaitu jangka waktu mulai adanya permintaan bahan baku pada supplier sampai bahan baku tiba di pabrik. Supplier lead time berpengaruh besar terhadap proses produksi karena bila terjadi keterlambatan pengiriman melebihi supplier lead time yang telah ditetapkan dapat menyebabkan keterlambatan dalam memulai proses produksi sehingga tidak dapat menepati jadwal yang telah ditetapkan dan memungkinkan keterlambatan dalam merespon permintaan konsumen.

\section{Pengukuran Perspektif Pembelajaran dan Pertumbuhan}

Pengukuran yang dilakukan pada perspektif ini adalah :

1) Employee Turnover

employee turnover adalah perpindahan karyawan dari perusahaan. Employee turnover merupakan petunjuk kestabilan tenaga kerja. Semakin tinggi 
turnover maka semakin sering terjadi pergantian tenaga kerja sehingga perusahaan akan dirugikan karena hiring cost dan training cost, tidak optimalnya penggunaan alat-alat produksi selama masa training, dan kurangnya kemampuan produksi karyawan baru.

$$
\text { Employee turnover }=\frac{\text { number of total separation }- \text { unavoidable }}{\text { average number of employee }} \times 100 \%
$$

\section{2) Absenteism}

absenteism adalah lamanya waktu kerja yang hilang pada saat pekerja tidak hadir dalam pekerjaannya.

$$
\text { Percentage Lost Time }=\frac{\text { days lost to absenteism for a period }}{\text { average number of employee } x \text { total days }} \times 100 \%
$$

Tingginya tingkat absenteism mencerminkan adanya masalah internal lingkungan kerja dan akan merugikan badan usaha, misalnya penundaan jadwal kerja dan penurunan produktivitas. Selain itu absenteism juga menunjukkan tingkat motivasi tenaga kerja sebagai salah satu aset perusahaan.

3) Employee Training Total

Manajemen akan berusaha mempertahankan pekerjanya yang mempunyai unjuk kerja yang tinggi, mempunyai skill dan berharga di mata perusahaan dalam jangka waktu yang lama. Untuk meningkatkan skill yang dimiliki para pekerja maka perlu dilakukan pelatihan atau training secara teratur, karena karyawan dengan ketrampilan dan wawasan yang luas bisa menjadi modal yang penting bagi manajemen perusahaan dalam mencapai tujuan dan target yang telah ditetapkan.

$$
\text { ETT }=\frac{\text { jumlah training }}{\text { jumlah karyawan }} \times 100 \%
$$

\section{Keunggulan Balanced Scorecard}

Balanced Scorecard sebagai inti sistem manajemen strategik memiliki empat keunggulan yaitu :

1. Memotivasi personel untuk berfikir dan bertindak strategik dalam membawa perusahaan menuju ke masa depan.

2. Menghasilkan total business plan yang komprehensif.

3. Menghasilkan total business plan yang koheren.

4. Keseimbangan sasaran strategik dalam empat perspektif guna memadukan rencana jangka panjang dan shareholder value.

5. Menghasilkan sasaran-sasaran strategik yang terukur.

(Mulyadi, Balanced Scorecard : Alat Manajemen Kontemporer untuk Pelipatganda Kinerja Keuangan Perusahaan, UGM, 2001, Hal : 63 )

\section{Pengukuran Konsistensi Setiap Matriks Perbandingan}

Konsistensi adalah jenis pengukuran yang tak dapat terjadi begitu saja atau mempunyai syarat tertentu. Suatu matriks, misalnya terdapat 3 unsur (i, j, k) dan setiap perbandingannya dinyatakan dengan a. Konsistensi $100 \%$ apabila memenuhi syarat sebagai berikut :

$$
a_{i j} \cdot a_{j k}=a_{i k}
$$


dengan syarat tersebut maka matriks A berikut ini dapat dinyatakan konsistensi karena :

$\mathrm{A}=$\begin{tabular}{c|ccc} 
& $\mathrm{i}$ & $\mathrm{j}$ & $\mathrm{k}$ \\
\hline $\mathrm{i}$ & 1 & 4 & 2 \\
$\mathrm{j}$ & $1 / 4$ & 1 & 3 \\
& $1 / 2$ & $1 / 3$ & 1
\end{tabular}

Apabila ketiga syarat diatas sudah terpenuhi maka bias dikatakan bahwa matriks A tersebut konsistensi $100 \%$ atau dapat juga dikatakan tingkat inkonsistensinya $0 \%$. Apabial muncul angka atau skala 5 dalam sebuah matriks perbandingan maka itu tidak lain adalah $5 / 1$.

Pengukuran konsistensi dari suatu matriks itu sendiri didasarkan atas suatu eigen value maksimum. Dengan eigen value maksimum, inkonsistensi yang biasa dihasilkan matriks perbandingan dapat diminimumkan.

Rumus dari indeks konsistensi (CI) adalah

$$
C I=\frac{\left(\lambda_{\text {maks }}-n\right)}{(n-1)}
$$

Berikut ini indeks random untuk matriks berukuran 3 sampai 10 (matrks berukuran 1 dan 2 mempunyai inkonsistensi 0)

\begin{tabular}{|c|c|c|c|c|c|c|c|c|}
\hline 12 & 3 & 4 & 5 & 6 & 7 & 9 & & \\
\hline 0.00 & 058 & 000 & 112 & 124 & 127 & 141 & 145 & 140 \\
\hline
\end{tabular}

Sumber : Analitical Hierarchy Process, Bambang Brodjonegoro, 1991

Rumus dari konsistensi / inkonsistensi (CR) itu sendiri dapat dituliskan sebagai berikut :

$$
\begin{array}{ll}
\mathrm{CR}=\mathrm{CI} / \mathrm{RI}, \quad \text { dimana }: & \mathrm{CR}=\text { Rasion Konsistensi } \\
& \mathrm{CI}=\text { Indeks Konsistensi } \\
& \mathrm{RI}=\text { Indeks Random }
\end{array}
$$

Tingkat inkonsistensi yang masih bias diterima adalah tingkat inkonsistensi sebesar $10 \%$ kebawah (Bambang PS Brodjonegoro, 1991 : 15)

\section{PEMBAHASAN}

\section{Kuisioner Kepuasan Pelanggan.}

Kuisioner kepuasan pelanggan merupakan hasil pengumpulan data primer yang di dapat dari kuisioner kepada para konsumen BPTI Logam \& LIK Sidoarjo. yang diambil tanpa ada pengklasteran berdasarkan karakteristik tertentu.

\section{Uji Validitas dan Realibilitas}

Kuisioner pengukuran kepuasan pelanggan terhadap konsumen BPTI Logam \& LIK Sidoarjo yang dihasilkan disebarkan sejumlah 50 buah kuisioner. Kemudian hasil kuisioner tersebut dilakukan uji validitas dan reabilitas dengan menggunakan software SPSS versi 12 . Suatu item pertanyaan akan dianggap valid jika corrected item total correlation ( $\mathrm{r}$ hitung) lebih besar dari nilai $\mathrm{r}$ kritis ( $\mathrm{r}$ tabel). Dapat dilihat pada tabel $r$ kritis (pada lampiran 1), dengan jumlah responden sebesar 50, maka derajad kebebasan (df) adalah n-2, yaitu sebesar 48, 
dengan menggunakan perhitungan hasil perhitungan yang berasal dari program SPSS maka dalam $r$ kritis ( $\mathrm{r}$ tabel) untuk tingkat toleransi kesalahan $5 \%$ sebesar 0.2353 , begitu juga kuisioner yang dianggab reliable atau andal jika nilai alpha lebih besar dari nilai $\mathrm{r}$ kritis ( $\mathrm{r}$ tabel).

Output SPSS versi 12 hasil uji validitas dan reliabilitas terdapat pada lampiran 2. Nilai corrected item total correlation untuk kuisioner kepuasan pelanggan pertayaan no satu sebesar 0,737 , karena nilai tersebut lebih besar dari $r$ kritis sebesar 0,2353 maka pertanyaan nomer satu kuisioner kepuasan pelanggan tersebut adalah sah / valid. Sehingga 5 item yang ada pada pertanyaan kuisioner kepuasan pelanggan tersebut adalah sah / valid, sebab nilai corrected item total correlation ledih besar dari dari nilai $r$ kritis atau nilai $r$ tabel yaitu sebesar 0,2353. Nilai alpha untuk kuisioner kepuasan pelanggan yang sebesar 0,772 adalah lebih besar dari $r$ tabel sebesar 0,2353 yang berarti kuisioner kepuasan pelanggan adalah reliable atau andal. Berikut merupakan rekapitulasi hasil uji validitas dan reliabilitas kuisioner kepuasan pelanggan.

Tabel 2. Rekapitulasi Uji Validitas Dan Uji Reliabilitas Kuisioner Kepuasan Pelanggan

\begin{tabular}{|l|c|c|c|}
\hline Item & corrected item total correlation & $\mathrm{R}$ tabel & Kesimpulan \\
\hline Uji validitas` & Kepuasan & & \\
\hline 1 & 0.737 & 0,2353 & Valid \\
\hline 2 & 0.525 & 0,2353 & Valid \\
\hline 3 & 0.734 & 0,2353 & Valid \\
\hline 4 & 0.356 & 0,2353 & Valid \\
\hline 5 & 0.420 & 0,2353 & Valid \\
\hline Uji reliabilitas (Alpha Value) & 0.772 & 0,2353 & Reliable \\
\hline
\end{tabular}

Sumber : Print Output SPSS

\section{Pembobotan dengan metode AHP}

Pembobotan dilakukan untuk mengetahui kontribusi masing-masing indikator terhadap kinerja perusahaan secara keseluruhan. Metode pembobotan yang digunakan adalah Analitycal Hierachy Process dengan bantuan software Expert Choice. Pembobotan yang akan dilakukan disini adalah :

a) Pembobotan antar prespektif

Pembobotan ini untuk mengetahui kontribusi mana yang paling besar terhadap kinerja perusahaan

b) Pembobotan antar KPI dalam prespektif

Pembobotan ini untuk mengetahui kontribusi masing-masing KPI dalam setiap prespektif terhadap kinerja perusahaan.

\section{Pembobotan Kinerja Perusahaan Keseluruhan}

Hasil pembobotan kelompok kinerja pada masing-masing Perspektif terhadap kinerja perusahaan secara keseluruhan dapat dilihat pada tabel berikut:

Tabel 3. Hasil Pembobotan Kinerja Perusahaan Secara Keseluruhan

\begin{tabular}{|l|c|}
\hline \multicolumn{1}{|c|}{ Kelompok KPI } & Bobot \\
\hline Financial & 0.389 \\
\hline Customer & 0.448 \\
\hline Bisnis Internal & 0.076 \\
\hline Learning \& Growht & 0.087 \\
\hline Jumlah & $\mathbf{1}$ \\
\hline
\end{tabular}




\begin{tabular}{|c|c|}
\hline Inconsistency Ratio & $\mathbf{0 . 0 1}$ \\
\hline Kesimpulan & Konsisten \\
\hline
\end{tabular}

Berdasarkan diatas maka perusahaan harus memprioritaskan customer dalam meningkatkan kinerjanya. Berikut ini akan diberikan contoh perhitungan pembobotan stakeholder dengan menggunakan langkah proses AHP sebagai berikut :

Tabel 4. Perhitungan hasil kuisioner pembobotan tiap perspektif

\begin{tabular}{|c|c|c|c|c|}
\hline & F & C & I & L \\
\hline F & $\mathbf{1}$ & $\mathbf{1}$ & $\mathbf{5}$ & 4 \\
\hline C & & $\mathbf{1}$ & $\mathbf{7}$ & 5 \\
\hline I & & & $\mathbf{1}$ & 1 \\
\hline L & & & & 1 \\
\hline
\end{tabular}

Keterangan :

$>$ F : Perspektif Finansial

$>$ C : Perspektif Pelanggan

$>$ I : Perspektif Proses Bisnis Internal

$>$ L : Perspektif Pertumbuhan dan Pembelajaran

Tabel 5. Matrik Perbandingan

\begin{tabular}{|c|c|c|c|c|}
\hline & F & C & I & L \\
\hline F & $\mathbf{1 . 0 0}$ & $\mathbf{1 . 0 0}$ & $\mathbf{5 . 0 0}$ & 4.00 \\
\hline C & $\mathbf{1 . 0 0}$ & $\mathbf{1 . 0 0}$ & $\mathbf{7 . 0 0}$ & 5.00 \\
\hline I & $\mathbf{0 . 2 0}$ & $\mathbf{0 . 1 4}$ & $\mathbf{1 . 0 0}$ & 1.00 \\
\hline L & $\mathbf{0 . 2 5}$ & $\mathbf{0 . 2 0}$ & $\mathbf{1 . 0 0}$ & 1.00 \\
\hline Total & 2.45 & 2.34 & 14.00 & 11.00 \\
\hline
\end{tabular}

Tabel 6.Matriks Perbandingan Hasil Normalisasi

\begin{tabular}{|l|r|r|r|r|r|r|}
\hline & \multicolumn{1}{l|}{ F } & C & \multicolumn{1}{l|}{ BI } & LG & JUMLAH & RATA \\
\hline F & 0,408 & 0,42 & 0,357 & 0,363 & 1,556 & 0,389 \\
\hline C & 0,408 & 0,42 & 0,5 & 0,454 & 1,790 & 0,447 \\
\hline BI & 0,081 & 0,059 & 0,071 & 0,090 & 0,303 & 0,07 \\
\hline LG & 0,102 & 0,08 & 0,071 & 0,090 & 0,349 & 0,087 \\
\hline & 1 & 1 & 1 & 1 & 4 & \\
\hline
\end{tabular}

Tabel 7. Matrik C

\begin{tabular}{|l|r|r|r|r|r|}
\hline & \multicolumn{1}{l|}{ F } & \multicolumn{1}{l|}{ C } & \multicolumn{1}{l|}{ BI } & LG & JUMLAH \\
\hline F & 1,556 & 1,790 & 1,518 & 1,399 & 6,264 \\
\hline C & 1,556 & 1,790 & 2,126 & 1,749 & 7,222 \\
\hline BI & 0,311 & 0,250 & 0,303 & 0,349 & 1,215 \\
\hline LG & 0,389 & 0,358 & 0,303 & 0,349 & 1,400 \\
\hline
\end{tabular}




$$
\left|\begin{array}{l}
6,264743 \\
7,222191 \\
1,215515 \\
1,400733
\end{array}\right|:\left|\begin{array}{l}
1,556293 \\
1,790059 \\
0,303799 \\
0,349849
\end{array}\right|=\left|\begin{array}{l}
4,025427 \\
4,03461 \\
4,001044 \\
4,003827
\end{array}\right|
$$

$\lambda$ maks $=\Sigma(4.025+4.03+4.001+4.003) / \mathrm{n}$

$=16.064 / 4=4.0162$

$\mathrm{CI}=(\lambda$ maks $-\mathrm{n}) /(\mathrm{n}-1)$

$=(16.064-4) /(4-1)$

$=0.009$

Berdasarkan pada Nilai Indeks Random diperoleh nilai RI adalah 0.90 sehingga

$$
\begin{aligned}
\mathrm{CR} & =\mathrm{CI} / \mathrm{RI} \\
& =0.009 / 0.90=0,01
\end{aligned}
$$

$\mathrm{CR} \leq 0,10 \rightarrow$ Data Konsisten

Untuk perhitungan indikator kinerja lainnya dapat dilihat pada lampiran 4

Dari perhitungan diperoleh bobot dari masing - masing kriteria adalah :

Financial

$$
=0.389
$$$$
=38.9 \%
$$

Customer

$$
=0.448
$$$$
=44.8 \%
$$

Bisnis Internal

$$
=0,076
$$$$
=7.6 \%
$$

Learning \& Growth $=0.087$

$$
=8.7 \%
$$

\section{Pembobotan pada Prespektif Financial} bawah ini.

Hasil pembobotan pada perspektif financial dapat dilihat pada tabel di

Tabel 8.Hasil Pembobotan KPI Financial

\begin{tabular}{|l|c|c|}
\hline Kelompok KPI Financial & Bobot & Bobot Global \\
\hline Return On Investment (ROI) & 0.413 & 0.160 \\
\hline Profit Margin On Sales (PMoS) & 0.360 & 0.140 \\
\hline Sales Growth & 0.120 & 0.046 \\
\hline Return On Assets (ROA) & 0.106 & 0.041 \\
\hline Jumlah & $\mathbf{1}$ & $\mathbf{0 . 3 8 7}$ \\
\hline \multicolumn{1}{|c|}{ Inconsistency Ratio } & \multicolumn{2}{|c|}{.01 } \\
\hline \multicolumn{2}{|c|}{ Konsisten } \\
\hline
\end{tabular}

Dari tabel tersebut dapat kita lihat bahwa Return On Investment (ROI) dianggap memberikan kontribusi terbesar terhadap kinerja perusahaan pada perspektif financial, diikuti oleh Profit margin on sales (PMoS), Sales Growth dan Return on Assets (ROA).

\section{Pembobotan pada Prespektif Customer}

Hasil dari pembobotan perspektif customer dapat dilihat pada berikut Tabel 9. Hasil Pembobotan KPI customer

\begin{tabular}{|l|c|c|}
\hline Kelompok KPI Prespektif Customer & Bobot & Bobot Global \\
\hline Jumlah Keluhan pelanggan & 0.376 & 0.168 \\
\hline Jumlah Kepuasaan Pelanggan & 0.474 & 0.212 \\
\hline Jumlah retur penjualaan & 0.149 & 0.066 \\
\hline
\end{tabular}




\begin{tabular}{|c|c|c|}
\hline Jumlah & 1 & 0.446 \\
\hline Inconsistency Ratio & \multicolumn{2}{c|}{0.05} \\
\hline Kesimpulan & \multicolumn{2}{c|}{ Konsisten } \\
\hline
\end{tabular}

Dari tabel di atas dapat dilihat bahwa jumlah kepuasaan pelanggan memiliki bobot terbesar terhadap kinerja perusahaan dari perspektif customer. Hal ini menunjukkan kalau pihak manajemen menginginkan agar kepuasaan pelanggan dapat terus terjaga dan tetap diperhatikan.

\section{Pembobotan pada Prespektif Bisnis Internal}

Hasil dari pembobotan perspektif Bisnis Internal dapat dilihat pada tabel berikut Tabel 10. Hasil Pembobotan KPI Bisnis Internal

\begin{tabular}{|l|c|c|}
\hline Kelompok KPI Prespektif Bisnis Internal & Bobot & Bobot Global \\
\hline Yield Rate & 0.405 & 0.030 \\
\hline Keterlambatan pengiriman bahan baku & 0.481 & 0.036 \\
\hline Prosentase produk cacat & 0.114 & 0.008 \\
\hline Jumlah Inconsistency Ratio & $\mathbf{1}$ & $\mathbf{0 . 0 7 4}$ \\
\hline Kesimpulan & \multicolumn{2}{c|}{ Konsisten } \\
\hline
\end{tabular}

Dari tabel diatas dapat dilihat bahwa menekan keterlambatan bahan baku merupakan indikator yang memiliki bobot terbesar yang sangat mempengarui proses bisnis internal di BPTI Logam \& LIK Sidoarjo.

\section{Pembobotan pada Prespektif Learning and Growth.}

Hasil pembobotan pada perspektif Learning and Growth dapat dilihat pada tabel berikut ini

Tabel 11. Hasil Pembobotan KPI Learning an Growth

\begin{tabular}{|l|c|c|}
\hline Kelompok KPI Learning and Growth & Bobot & Bobot Global \\
\hline Absensi Karyawan & 0.627 & 0.054 \\
\hline Employee TurnOver & 0.280 & 0.024 \\
\hline Training Karyawan & 0.094 & 0.008 \\
\hline Jumlah & $\mathbf{1}$ & $\mathbf{0 . 0 8 6}$ \\
\hline Inconsistency Ratio & \multicolumn{2}{|c|}{ Konsisten } \\
\hline Kesimpulan & \multicolumn{2}{|c|}{}
\end{tabular}

Dari diatas dapat dilihat bahwa absensi adalah indikator meningkatnya atau tidak pembelajaran dan pertumbuhan, selain itu keluar masuknya karyawan (Employee turnover) juga mempengarui proses pembelajaran dan pertumbuhan di BPTI Logam \& LIK Sidoarjo.

\section{Perhitungan Skor KPI (Key Performance Indicators)}

Untuk melakukan perhitungan skor terhadap masing-masing KPI yang telah teridentifikasi, data yang diperlukan dengan mengambil data historis pada tahun 2007 dan 2008 yang meliputi : 
Tabel 12. Data Pengukuran Kinerja dari masing-masing KPI

\begin{tabular}{|c|c|c|c|c|c|}
\hline $\begin{array}{l}\text { No. } \\
\text { KPI }\end{array}$ & KPI & $\begin{array}{l}\text { Kondisi } \\
\text { awal } \\
\text { (Score 3) }\end{array}$ & $\begin{array}{c}\text { Kondisi } \\
\text { akhir } \\
\text { (Performan } \\
\text { ce) } \\
\end{array}$ & $\begin{array}{l}\text { Target } \\
\text { (Score } \\
10)\end{array}$ & $\begin{array}{c}\text { Kondisi } \\
\text { terburuk } \\
\text { (Score } 0)\end{array}$ \\
\hline \multicolumn{6}{|c|}{ Perspektif Financial } \\
\hline KPI 1 & Return On Investment (ROI) & 8.12 & 6.16 & 10 & 5 \\
\hline KPI 2 & Profit Margin On Sales (PMoS) & 24 & 19.57 & 25 & 16 \\
\hline KPI 3 & Sales Growth (SG) & 3 & 1.1 & 5 & 0.5 \\
\hline KPI 4 & Return On Assets (ROA) & 5.9 & 4.52 & 7 & 3 \\
\hline \multicolumn{6}{|c|}{ Perspektif Customer } \\
\hline KPI 5 & Keluhan Pelanggan & 2.3 & 1.6 & 1.1 & 3.5 \\
\hline KPI 6 & Kepuasaan Pelanggan & 900 & 1024 & 1250 & 750 \\
\hline KPI 7 & Retur Penjualaan & 2 & 1.8 & 1 & 3 \\
\hline \multicolumn{6}{|c|}{ Perspektif Bisnis Internal } \\
\hline KPI 8 & Yield Rate & 0.958 & 0.963 & 0.98 & 0.9 \\
\hline KPI 9 & Keterlambatan bahan baku & 7.25 & 6.86 & 5 & 8.5 \\
\hline KPI 10 & Prosentase Produk Cacat & 4.2 & 3.7 & 3 & 6 \\
\hline \multicolumn{6}{|c|}{ Perspektif Learning and Growth } \\
\hline KPI 11 & Absensi & 3.38 & 3.25 & 2 & 4 \\
\hline KPI 12 & Employee Turnover & 3.6 & 1.8 & 1 & 4.6 \\
\hline KPI 13 & Training karyawan & 1.8 & 3.7 & 4 & 0.9 \\
\hline
\end{tabular}

- Score 3 merupakan kondisi kinerja awal penelitian yaitu tahun 2005. Nilainilai tersebut dimasukkan dalam matrik objectives pada baris score 3 sehingga dapat diketahui kondisi awal setiap Key Performance Indicator (KPI) pada tiap perspektifnya

- Performance merupakan kondisi kinerja saat ini yaitu tahun 2006. Nilainilai tersebut dimasukkan dalam matrik objectives pada baris performance sehingga dapat diketahui kondisi saat ini setiap Key Performance Indicator (KPI) pada tiap perspektifnya

- Score 10 merupakan target kinerja perusahaan dilihat dari Key Performance Indicator (KPI) nilai tersebut ditentukan pihak manajemen perusahaan. Nilai-nilai tersebut dimasukkan dalam matrik objectives pada baris score 10 sehingga dapat diketahui target yang harus dicapai setiap Key Performance Indicator (KPI) pada tiap perspektifnya

- Score 0 merupakan kondisi terburuk dari kinerja perusahaan dilihat dari Key Performance Indicator (KPI) nilai tersebut ditentukan pihak 
manajemen perusahaan. Nilai-nilai tersebut dimasukkan dalam matrik objectives pada baris score 0 sehingga dapat diketahui kondisi terburuk menurut pihak manajemen perusahaan setiap Key Performance Indicator (KPI) pada tiap perspektifnya

\section{Hasil Pengukuran Kinerja Dengan Metode OMAX}

Pengukuran kinerja akan dilakukan dengan metode Objective Matrix, yang disertai dengan Traffic Light System untuk memberi tanda apakah masingmasing indicator kinerja mengalami suatu peningkatan atau tidak. Traffic Light System memiliki tiga warna yaitu hijau untuk indikator kinerja dengan nilai 8,1-10 yang berarti KPI dari perusahaan sudah tercapai, kuning untuk indikator kinerja dengan nilai 3,1-8,0 yang berarti KPI dari perusahaan belum tercapai dan diperlukan usaha yang lebih baik untuk mencapainya. Warna merah untuk indikator kinerja bernilai kurang dari atau sama dengan 3,0 yang menandakan bahwa KPI dari perusahaan benar-benar dibawah target sehingga harus ada fokus perbaikan yang berkesinambungan untuk merubahnya.

\section{Scoring system}

Metode scoring system yang digunakan untuk mengukur kinerja perusahaan adalah dengan menggunakan objektive matrix, yang bertujuan untuk mengetahui level pencapaian KPI terhadap target yang telah ditentukan, nilai kinerja (level) masing-masing KPI, indikator pencapaian (curent) perusahaan dan indexs produktivitas perusahaan secara keseluruhan.

Data untuk pencapaian kriteria tersebut didapat dari data internal perusahaaan dan wawancara terhadap pembimbing pabrik dan karyawan tiap bagian yang bersangkutan.

Setelah itu dilakukan konversi dengan melihat nilai pada kolom level yang paling mendekati nilai performance sebesar 6.16, yaitu level 1 (6.04). bobot untuk KPI 1 adalah sebesar 0.160 sehingga value yang diperoleh adalah 0.160 dikalikan dengan 1, yaitu sebesar 0.160

Index produktivitas sebagai berikut :

$$
\text { Index }=\frac{\text { current }- \text { previous }}{\text { previous }}=\frac{4.26-3}{3}=0.42
$$

Indeks produktivitas ini menunjukkan bahwa kinerja perusahaan telah meningkat sebesar 0.42 kali dari kinerja sebelumnya.

\section{Penilaian Level KPI}

Setelah dilakukan pengukuran kinerja dengan menggunakan metode OMAX, selanjutnya dilakukan tahap penilaian level KPI, yang menggunakan asumsi sebagai berikut:

- Jelek untuk level KPI yang terdapat pada level 0 sampai 3.

- Cukup untuk level KPI yang terdapat pada level 4 sampai 7

- Baik untuk level KPI yang terdapat pada level 8 sampai 10.

Asumsi penilaian level tersebut telah diverifikasi kepada pihak pimpinan perusahaan.

\section{Upaya Perbaikan}


Berdasarkan hasil scoring dengan Objective Matrix dan Traffic Light System, maka indikator kinerja merah dapat diusahakan perbaikannya oleh pihak manajemen. Indikator kinerja merah perlu mendapatkan perhatian secara khusus dengan tidak mengesampingkan indikator kinerja kuning dan hijau. Diharapkan dengan komitmen dan usaha perusahaan, maka perusahaan dapat meningkatkan kinerjanya secara maksimal. Upaya perbaikan dapat dilihat pada berikut

Tabel 13. Upaya Perbaikan untuk Indikator Kinerja Merah

\begin{tabular}{|c|c|c|}
\hline No & KPI & Upaya Perbaikan \\
\hline KPI 1 & $\begin{array}{l}\text { Return Of } \\
\text { Investment } \\
(\text { ROI) }\end{array}$ & $\begin{array}{l}\text { - Meningkatkan penjualan produk perusahaan agar net income } \\
\text { juga meningkat. } \\
\text { - Meningkatkan kualitas dari produk yang dihasilkan, agar } \\
\text { dapat semakin meningkatkan nilai penjualaan. }\end{array}$ \\
\hline KPI 2 & $\begin{array}{l}\text { Profit Margin } \\
\text { on Sales } \\
\text { (PMOS) }\end{array}$ & $\begin{array}{l}\text { - Melakukan promosi maupun pricing strategy untuk } \\
\text { meningkakan penjualan. } \\
\text { - Penghematan biaya operasional untuk mengurangi Harga } \\
\text { Pokok Produksi. } \\
\text { - Meningkatkan kinerja marketing. }\end{array}$ \\
\hline KPI 3 & $\begin{array}{l}\text { Sales Growth } \\
(S G)\end{array}$ & $\begin{array}{l}\text { - Penggunaan sumber daya termasuk tenaga penjualan untuk } \\
\text { meningkatkan penjualan. } \\
\text { - Meningkatkan pendapatan dengan upaya pemasaran melalui } \\
\text { peningkatan inovasi dan desain untuk produk yang dihasilkan. } \\
\text { - Mengendalikan biaya-biaya operasional perusahaan. } \\
\text { - Meningkatkan kinerja marketing serta promosi kepada } \\
\text { masyarakat. }\end{array}$ \\
\hline
\end{tabular}

\section{KESIMPULAN}

Dari hasil pengukuran kinerja di BPTI Logam \& LIK Sidoarjo maka dapat diambil beberapa kesimpulan yaitu :

1. Tingkat kinerja di Balai Pelayanan Teknis Industri Logam Sidoarjo sebesar 4.26 yang secara keseluruhan berada pada indikator kuning, yang berarti memerlukan kewaspadaan karena masih belum mencapai target yang diharapkan oleh BPTI Logam Sidoarjo.

2. Perbaikan yang harus dilakukan untuk Key Performance Indicators (KPI) dengan indikator warna merah yang berarti pencapaiannya benar-benar jauh dibawah target dan perlu segera perbaikan sebagai berikut :

a) KPI Return Of Investment (ROI).

Perbaikan yang dilakukan adalah dengan cara meningkatkan penjualan produk perusahaan agar net income juga meningkat dan meningkatkan kualitas dari produk yang dihasilkan, agar dapat semakin meningkatkan nilai penjualaan.

b) KPI Profit margin On Sales (PMoS).

Melakukan promosi maupun pricing strategy untuk meningkakan penjualan, dan meningkatkan kinerja marketing.

c) KPI Sales Growth ( $S G)$

Penggunaan sumber daya termasuk tenaga penjualan untuk meningkatkan penjualan, meningkatkan pendapatan dengan upaya pemasaran melalui 
peningkatan inovasi dan desain untuk produk yang dihasilkan, mengendalikan biaya-biaya operasional perusahaan

\section{DAFTAR PUSTAKA}

Mulyadi. (2001). "Balanced Scorecard : Alat Manajemen Kontemporer Untuk Pelipat Ganda Kinerja Keuangan Perusahaan", Penerbit Salemba Empat.

Nanus, Burt. Dan Bennis, Warren. (1990), "Kepemimpinan: Strategi Dalam Mengemban Tanggung Jawab" Penerbit Erlangga, Jakarta

Permadi, Bambang. (1992) "AHP" Pusat Antar Universitas - Studi Ekonomi Universitas Indonesia, Jakarta

Saaty, T.L (1991), Pengambilan Keputusan Bagi Para Pemimpin: Proses Hirarki untuk Keputusan dalam Situasi yang Kompleks, PT. Pustaka Binaman Pressindo.

Kaplan, Robert S. dan David Norton, "Menerapkan StrategiMenjadi Aksi Balanced Scorecard”, 1996, Penerbit Erlangga, Jakarta.

Vincent Gaspersz, Sistem Manajemen Kinerja Terintegrasi Balanced Scorecard dengan Six Sigma Untuk Organisasi Bisnis\&Pemerintah, 2003, PT. Gramedia Pustaka Utama, Jakarta.

Tjahjono, Heru Kurnianto, Budaya organisasional dan Balanced ScoreCard, 2003, Unit Penerbitan Fakultas Ekonomi Universitas Muhamadiyah Yogyakarta. 